\title{
8. Debating the Speaker
}

\author{
John Uhr
}

Rhetoric refers to the political language used by Australian politicians to lead and shape public opinion. Successful rhetoric is influential rhetoric: words that form a following. Effective rhetoric can be true or false or some mixture in between. Democratic theories about political rhetoric tend to avoid strict stipulations about truthfulness or falsity, referring more to the process of facilitating fair debate among competing political players, rather than the content of that debate. Democratic political rhetoric faces norms of due process about the public scrutiny and accountability of political debaters. I frame a form of accountability for Australian political rhetoric, providing one instance of how greater public knowledge and accountability of parliamentary rhetoric can improve public understanding of Australian parliamentary politics.

Rhetoric reveals leadership strategies that are used in the public argument among those competing for public support. Ryan Walter and I are examining patterns of Australian political rhetoric during the last Parliament under the minority government of Julia Gillard and Kevin Rudd (2010-13). Our theme is that the minority government formed after the 2010 election and led for the most part by Gillard (before Rudd's return to the prime ministership in July 2013) revealed in unusual ways many important features of Australian political rhetoric. The minority government was an unusual type of national government, with parliamentary politics shifted from the conventional binary mode of two-party competition between government and Opposition to a multiparty competition across all parliamentary players in both houses of the national Parliament.

Parliamentary rhetoric is the most carefully scripted and staged form of political rhetoric. The institutional setting of Parliament establishes the public stage and routines of stagecraft that are open to elected members. Usually the stage of the House of Representatives over-represents the government of the day and under-represents non-government parties. The period of the Gillard/Rudd minority government changed this dramatic routine by bringing forward a clearer public display of many of the antagonistic forces at work in Australian political rhetoric. Our initial interest is to make the best research use we can of the unconventional display of political completion fostered by the period of minority government, when so many political parties and interests sought the public stage to legitimate their current role in the governance process and to broaden public support for their preferred role after the 2013 election. 


\section{The Speakership}

This chapter examines Australian political rhetoric relating to the role of the Speaker of the House of Representatives during the period of the Gillard minority government. The intention is not to highlight Speakers as great political speakers, but to show how debates over the role of the Speaker clarify important themes in Australian political rhetoric (Snedden 1980; Healy 1998). This chapter reports things said by the three Speakers from 2010-13; but the main story is about what they and others have said about the office and role of the Speakership as part of a central debate about one of the few constitutional offices ordering Australian parliamentary politics. The type of institutional order that Speakers bring to Australian politics depends substantially on the powers and responsibilities Parliament delegates to them, historically and currently (House of Representative (HR) 2012: 187). In most parliaments, the Speakership is not the subject of sustained debate. On this theme, the value of the Gillard minority government is that it generated sustained political debate over the Speakership in a rare rhetorical contest over the political norms expected of the constitutional leader of the House of Representatives.

The topic here is political rhetoric about Speakers and not the political rhetoric of Speakers, which would include not only what is said, but how it is said, including the role of gowns and wigs favoured by traditionalists and opposed by Labor (Bolton 1968, 155; HR 2012: 162). What leading Australian members of the House of Representatives can do on the parliamentary stage depends substantially on the licence or punishment given to them by the Speaker (Inglis 1996). Yet Speakers themselves do not really belong to the same political set as party leaders: Speakers speak differently precisely because their political office differs, in ways that are shaped by the sparse provisions in the Australian constitution. Speakers manage the deliberative process according to rules authorised by the House. The constitution denies Speakers (and only Speakers) a deliberative vote, which is a prominent way of separating Speakers from other members of the House. To a considerable extent, Speakers seldom speak as political deliberators about the merits and content of public policy. But, to an even greater extent, Speakers speak about the merits of the process of parliamentary deliberation over which they preside. The constitution says little about the larger purposes of this presiding officer, or indeed of the Senate's presiding officer, and this gives great power to the House to specify the delegated powers exercised by Speakers as presiding officers.

The Gillard/Rudd minority government had three Speakers over its threeyear term: Victorian Australian Labor Party (ALP) member Harry Jenkins; Queensland former Liberal and former National party member Peter Slipper; and Victorian ALP member Anna Burke. What is remarkable is that the ALP 
government appointed a non-ALP member, Slipper, as its second Speaker, in an unusual attempt to reduce the voting strength of the official Opposition and to increase the voting strength of the governing minority party. Slipper later resigned from the Speakership when facing two criminal charges: one over mismanagement brought by one of his official staff, which Slipper later won; and one over misconduct brought by the Australian Federal Police, which is still awaiting hearing. Most Australian national governments retain one person as Speaker for each parliament or period of government. A few have had more than one, but very few have had three. The Gillard/Rudd minority government made the choice to have more than one in an attempt to manage its minority position; it later made the choice to have more than two when the controversy over Slipper's alleged misconduct brought the original choice into question.

The Speaker is one of the few national political offices defined in the Australian constitution, which has nothing to say in its original version about political parties, the prime minister or the leader of the Opposition. Constitutional amendments in 1977 introduced the first acknowledgement of the place of political parties in order to regulate state choice over replacement senators. My focus here is on the limited role of the Speaker as a constitutional source of debate and disagreement in Australian political rhetoric. The Speaker is not as powerful a political office as many of those other House of Representatives' offices not mentioned in the constitution, such as the prime minister, or leader of the Opposition, or even leader of government in the House. But the Speaker's role is powerful enough to have become the subject of protracted political wrangling during the period of the Gillard/Rudd minority government, as government and Opposition used many rhetorical strategies to promote or oppose the use and abuse of the role. This debate over who can and should be Speaker provides us with a case study of Australian political rhetoric, with a gallery of portraits depicting how different political players and interests define the constitutional characteristics of this basic public office.

The conclusion to be drawn from this is more about parliament than the Speaker. Parliament, or at least the House of Representatives, sets the standards for this core constitutional office (Snedden 1980). My interest is in debate over the Speakership as evidence of a group portrait of political opinion over parliamentary process. The Speaker is the core of the system of self-regulation established by the constitution. Other parts of the regulatory arrangements can come and go, but the Speaker (or a Speaker at least) remains. What elected members say about the Speaker reflects what they think not just about the independence of that public office, but about the independence of Parliament itself, including the independence of Parliament from more powerful forms of a Speaker, which might be consistent with the constitution, but would require sustained parliamentary support. The constitution does little more than identify 
the office as the first to be filled by a newly elected Parliament, implying that the Speaker is central to the larger operation of the House of Representatives. This permissive quality allows each House to support, modify, or restrict whatever practical functions might be expected of successive Speakers.

The debate during the Gillard/Rudd minority governments reveals something important about Australian parliamentary expectations of a Speaker. The Speaker judges the parliamentary conduct of members; thus the Speaker acts like a judge or, more properly, like a presiding officer responsible for due process of the chamber. As presiding officer, the Speaker's presence stems from their supposed 'independence' from a political (especially governing) party. That 'independence', however, does not confer a substantial positive role to determine positive standards of orderly conduct or to regulate what is expected of members. No Speaker has such a degree of independence that they can ignore party interest and introduce what many in the community might like: rules for non-partisan standards of orderly conduct. The Speaker's independence cuts the other way, with important discretionary judgement against disorderly conduct. The 'independence' does confer a substantial negative role to curb disorder and to punish members for their disorder. The extensive debate provides us with detailed evidence that a core role of the Speaker is, according to the standing orders, to 'maintain order' in Parliament by punishing disorderly conduct. The standing orders go some way to stipulating required order, but the role still requires important discretionary judgement by Speakers to rule against disorderly conduct, regardless of any political party interest (HR 2012, 174-76).

\section{The constitution}

One simple way of indicating the relative power of the office of Speaker is through the Remuneration Tribunal, which places the two presiding officers as the highest paid parliamentary office holders. They receive less salary than the leader of the Opposition but substantially more than any other holder of a non-government office. Their salary is slightly above that of cabinet ministers, equating to that of the leader of the House (or Senate) who manages government business (Remuneration Tribunal 2012, 2013).

A less simple indication is in the constitution, which provides for the office of the Speaker. Of interest is the fact that the constitution provides for the president of the Senate earlier than the Speaker, and differently from the Speaker: the president, like the Speaker, is elected by the House; unlike the Speaker, however, the president has a vote on 'questions arising in the Senate', but no casting vote (as this would break the equal representation of the states). Tied Senate votes are held to be negative $(\mathrm{ss} 17,22)$. The constitution provides for the Speaker as 
the only office required for formal proceedings of the House of Representatives. Before any other business, the House chooses ('elects', according to the heading in the constitution) one of its members to be Speaker and may remove a Speaker by 'a vote of the House' (s35). The Speaker does not have a vote on 'questions arising in the House', but instead has, following British practice, a 'casting vote' to break tied votes in the House (s40) (HR 2012: 163).

The constitution does not clarify what principles Speakers would or should apply when making casting votes. This issue is important for it goes to one of the few distinctive powers of Speakers (Murray 2002). Casting votes only arise when votes in the chamber are equal, implying that a governing party cannot enforce its own vote except with the assistance of the Speaker. In this case, several options might apply (HR 2012: 182-86). One would be always to vote with the governing party; but this would also imply that Speakers were taking close note of the partisan nature of the dispute and regarding the party in government as the primary party to support. Such an option does not tally with the norms of impartiality noted below. Another option is that the constitution anticipates no restrictions on the principles Speakers may apply. This option would allow Speakers great freedom to apply whatever principles they consider appropriate. But a third option is that the constitution leaves determination of the classification of relevant principles to the House. This third option places Speakers under the rule of the House, applying only those sorts of principles considered appropriate by the House. This is a difficult situation to envisage, given that casting votes only arise when opinion is equally divided between government and opposition, such that there is no House view or consensus to follow.

What is the formal constitutional duty of the two presiding officers? The precise content of these duties are left to the conventions of Parliament. John Quick and Robert Garran include two relevant quotations about British conventions: one from James Bryce about official integrity and the requirement for political impartiality (Bryce 1889: vol. 1, 134-35); and one from Erskine May about operational duties through the maintenance of order and due process (Quick and Garran 1976: 479-80). Quick and Garran explain what they think the duties of the president of the Senate are, but do not provide similar commentary on the duties of the Speaker (Quick and Garran 1976: 441). The Senate's presiding officer is defined in part by reference to the other house: for example, the president is to protect against invasions of 'the privileges of the Senate'. While the Speaker is given no specific role, the general duties of 'the presiding officers of legislative bodies' cover both presiding officers and include duties of maintenance, enforcement, appointment and supervision - all suggesting that the presiding officer exercises procedural but not substantive authority. They 
regulate, but they do not rule, as can be seen from their core duties: 'to maintain order and decorum; to enforce the rules of debate; ... to appoint tellers to take a division; to supervise the officers of the House' (Quick and Garran 1976: 441).

\section{The minority government}

The 2010 election is now famous for producing minority government after a messy process of post-election negotiation. Also famous in this period of negotiation are three episodes relating to debates over the 'independence' of the Speaker. The rhetoric of 'independence' dominates these episodes, as Australian shorthand for the traditional Westminster system of Speakership, which has never matched Australian practice (Bolton 1968; Andrew 2002).

\section{Non-government speaker}

The first episode relates to the Gillard government's intent in securing nongovernment interest in the office of the Speaker, perhaps inspired by the ALP's success at state and territory level to persuade non-government members to take on this important role (Murray 2002). Former member for Lyne Rob Oakeshott was targeted as a potential Speaker (Milne 2010). He famously declined to pursue this interest once he learned from the likely leader of the Opposition, Abbott, that the Labor plan for proposed pairing of Speaker and deputy Speaker was unconstitutional, according to advice very critical of Oakeshott prepared by shadow Attorney-General Senator George Brandis (2010a, b). A number of Liberal members, mostly towards the end of their parliamentary careers, were also rumoured to be interested. This openness to non-government models of a Speaker for a minority ALP government gave rise to wider discussion about reforms to the parliamentary office to make it consistent with the 'independent' model required of a reformed parliament.

The primary theme here is the contrast between the model being promoted and the practices of past parliaments, when many governments tolerated only modest independence in their Speakers. Typically, past discussion about 'independent' Speakers came from non-government and especially Opposition interests. What was new in 2010 was that discussion now included the governing ALP party precisely because it thought it could benefit from 'independence': curtailing the voting power of the non-government ranks by appointing a nongovernment member as Speaker. The relevance is that members of the newly elected Parliament sensed that whoever was Speaker would be expected to act against the inherited ways of past Speakers and past Parliaments, or at least past governments of the day, who tended to see the Speakership as an important government office. 


\section{Independent Speaker}

Episode two relates to the remarkable Agreement for a better Parliament: parliamentary reform of September 2010, which reflects the widespread views of the newly elected Parliament on institutional reform (ABP 2010). The document recognises the need for the Speaker 'to rule with a firm hand' under the 'cultural change' of enhanced participation being promoted. The 'independent Speaker' is listed as item two on the 22 items of proposed parliamentary reform. The Speaker's stated power is to 'rigorously enforce' the standing orders: and a new standing order relating to the direct relevance of answers to oral questions is later identified as requiring a 'strong stance' from the Speaker, eventually with support from government and opposition (ABP 2010: para 4.5). Independence explicitly means 'independent of Government'. Both the government-derived Speaker and Opposition-derived deputy Speaker will 'abstain from attending their respective party rooms' and also 'when in the Chair' they will be 'paired for all divisions', as will other members of the Speaker's panel when acting in the chair. This is the 'independence' plan opposed by the Opposition as unconstitutional because it potentially breaches the Speaker's duty to use the casting vote to resolve tied votes.

\section{Paired Speaker}

Episode three includes the formal reference from the Attorney-General to the Solicitor-General for an opinion about the 'independence' of the Speaker, delivered on 22 September (Gageler 2010). The Opposition had raised public doubts about pairing requirements for the Speaker, later using the SolicitorGeneral's advice as proof of its own case against the proposed pairing scheme (Brandis 2010a, b; Elder 2013: 3-4). Solicitor-General Stephen Gageler's 19-page report to Attorney-General Robert McClelland generally agrees with this opinion, although the main theme of this advice is whether there is 'any necessary constitutional impediment' to the pairing arrangement. The SolicitorGeneral answered that there was no 'necessary' constitutional impediment, so long as 'two provisos' were met: first, the Speaker's casting vote could not be deprived and the Speaker could not be given a normal deliberative vote; second, the pairing arrangement with the non-government deputy Speaker 'could only be voluntary' (Gageler 2010).

Brandis drew attention to the 'deliberately elliptical' language and argument from the Solicitor-General, which at times was 'striking in its circularity' (Brandis 2010b: 7, 9). The narrow logic of the Solicitor-General's advice was that the constitution did not prevent the government scheme. But the wider logic implied that the government had no power to compel any non-government member to any pairing arrangement, and indeed that Speakers should not act 
in ways that might interfere with another member's deliberative vote (Brandis 2010b: see, for example, paras 41-42). The Solicitor-General's advice reviewed the Agreement's details on the independence of the Speaker, noting that House members might not exercise their deliberative vote under limited circumstances (for example, conflict of interest, breach of privilege inquiry), while also noting that there can be no parliamentary enforcement of 'pairing' as a form of nonvoting, which might, quoting the House of Representatives Practice, 'operate as a matter of moral or political obligation' (Brandis 2010b: paras 32,40). So long as the Speaker did not use a pairing arrangement to exercise influence over deliberative votes by other members, the government scheme was not unconstitutional: or 'not necessarily unconstitutional', according to Brandis (2010c: 827).

Whether it was 'constitutionally proper', or fully or properly constitutional, was another issue, not asked of the Solicitor-General by the government (Brandis 2010b: para 5). Debate over the deeper meaning of the Solicitor-General's opinion arose in the House of Representatives at the election of Jenkins as Speaker, with Anthony Albanese defending government strategy by reference to the opinion and Christopher Pyne citing the more explicit criticism from Brandis as evidence against the government.

\section{Three tales of departure}

How then can we compare the rhetorical frameworks generated by these three Speakers? One useful approach is to compare the rhetorics associated with their decline from office: these transitions have provoked significant political commentary on the parliamentary roles of presiding officers. The warm praise of welcome found at the time of each Speaker's election reflects the high point of good intentions that every Parliament needs to experience; but the cold dismay found at the time of departure from office reflects more fundamental misgivings about the many roles managed by the House when selecting or replacing its Speaker.

The three tales of departure differ and reflect three competing models of what the House expects of Speakers. Jenkins's resignation upset two norms: that of a party loyalist taking the high office and that of retaining in office a Speaker with the technical skills to do the job well. Slipper's resignation upset the risky innovation of offering the office to a non-government member, but it reinforced the unwritten rule that admirable personal character is a basic requirement of this high public office. Burke's departure reasserts the norm of the rights of a party in government to award the office to one of its own members and it will dampen tendencies that occupants, like Jenkins and Burke, might have to steer the Speakership towards stronger forms of impartiality. 
Jenkins resigned with little public expectation that his time was up. He has spoken very little about that political decision, except to convey the impression that he was searching for greater opportunities to play active policy roles in the governing party. He went on to become chair of an important parliamentary committee on human rights, before retiring from Parliament at the 2013 election. Jenkins was widely admired for his technical skills as a manager of parliamentary deliberation; but he was also a frustrated custodian of the civilities that were frequently abused, often during question time, by many House members. Voters can see why such a champion of impartiality might have had enough; but many non-government members feared that his resignation was a forced event, initiated by the government to yet again try to find a nongovernment member to take the Speaker's job.

There is plenty of evidence to explain why the Gillard minority government could be persuaded that such a move would strengthen their voting power while weakening that of the Opposition, as it did. The timing of such a move can be explained by the growing threats of criminal charges against a government backbencher and the readiness of an Opposition member to take the risk in the final years before retirement. What does the Jenkins' resignation tell us about Australian political rhetoric? I think it tells us that the presiding office is a government gift, to be arranged and rearranged by the government of the day: carefully during times of majority government, and somewhat slyly during times of minority government. The fact that someone so technically gifted and admired came and went at times to suit the serving governments helps clarify the real burdens placed on even the best of Speakers.

Slipper departed in two stages: first by stepping aside from the office while criminal charges were being brought against him; and, later, by resigning after his narrow win over the Opposition's motion to vote him out of office. Slipper, a selfdescribed colourful figure, surprised many with his firm but fair presiding qualities as Speaker, taking on an active role as the 'dressed-for-office' representative of the House, ready to parade to the chamber in attempt to return dignity to parliamentary business. Slipper's departure is marked by the contrast between his elevated public and official style and the questionable personal style of a member not only facing criminal charges for mistreating employees and misusing travel privileges, but also for displaying offensive personal conduct in the email and telephone communications that were circulated during the court process.

Slipper's departure was as political as it was personal in that Opposition activists discredited him as personally unfit to hold high public office. That the Federal Court in turn discredited many of Slipper's most influential critics did little to save him, who had by then already returned to the isolation of the independent back bench. What does the Slipper tale of departure tells us? It reinforces the need for evidence of personal integrity in positions of public integrity and 
that, again, governments have accountability obligations when they appoint undeserving persons to high parliamentary office. The Opposition knew that the Gillard government was playing with fire in appointing Slipper, one of their former members, as Speaker. The government attempted to share the blame by making the Opposition, even the Leader of the Opposition, accountable for not regulating Slipper as one of their poor performers. The government lost and the Opposition won. Although critics of Slipper acknowledge his valuable deftness as a fair umpire of parliamentary debate, they also lament his unacceptable offchamber misconduct, which destroyed his constituency (Craven 2012; Marr 2013).

Burke's departure was delayed and was not officially resolved until the newly elected House of Representatives officially elected a new Speaker on its first day of sittings in November 2013. This standard Australian story of departure tells us something important about the ground rules of impartiality in Australian parliamentary politics. Incoming governments do not retain Speakers from their political opponents. Burke experienced the partisan rivalry of the final year or so of the minority government and her parliamentary comments on the decline in parliamentary civility are matched by her increasing criticism of disorderly conduct. Burke acted as well as any other good Speaker in managing parliamentary deliberation and her departure will reflect the greater power of party government, with a preference for one of its own as the House's impartial presiding officer.

Burke illustrates the best available in the standard model of House Speakers: coming late to the office after serving long in the Speaker's panel of junior officers, managing the mess left from earlier misadventures in the Speakership, and finally accepting the convention that the newly elected House will confer the honour of the Speakership on one of the new governing party's favoured members.

\section{Three debates over the Speaker}

The following sketches give a richer picture of the rhetorical tone generated by the rise and fall of each of the three Speakers. My interest is not to document their own particular rhetorical signatures but to use their anxiety in office to highlight wider institutional perspectives on parliamentary politics. What follows are three brief accounts of the prevailing tone of parliamentary argument sparked by each Speaker.

\section{Speaker Jenkins}

Jenkins (a son of a former Speaker), having served close to 12 years as deputy Speaker during the Howard governments, took office at the time of the Rudd government in 2008 and remained in place after the 2010 replacement of Rudd 
by Gillard (Elder 2013: 5-6). Jenkins was uncontested in this election and his first term in office is remarkable for the cross-party support provided by the Opposition. Displaying important party-political independence, he avoided ALP meetings about political and parliamentary tactics, although he maintained his association with party meetings about broader policy issues. This traditional experience of the Speakership changed after the 2010 election, mainly because the 'new paradigm' for the new parliament placed a heavy burden on the Speaker to act as the champion of procedural reform. Public rhetoric had not changed, but the internal complexity of multi-party negotiation certainly had (Wright 2013).

Another important factor in this change was the Opposition sense that the minority government could fall at any moment; this expectation placed additional burdens on the Speaker as a potential casualty of any such fall. No Commonwealth Speaker had functioned under such challenging circumstances of minority government since the early 1940s (Bolton 1968: 159-60; HR 2012: 166). Each sitting day provided fresh examples of the awkward balancing act required of Speakers when managing the parliamentary stage, especially during critical episodes, such as question time. The Opposition tended to interrupt question time with motions to suspend standing orders to bring on want of confidence motions against the government, thereby stretching ordinary goodwill between government and Opposition and establishing uncertainty for the House cross-benchers.

These circumstances would test even the most placid of Speakers. Jenkins, who emerged from the Rudd government experience with a reputation for impartiality, was sorely tried under the minority system, when so many House interests looked to the Speaker to promote a sense of order consistent with their own interests. Given that the minority system had not been tried for so many years, the House was divided with competing priorities and with steadily increasing friction between the two major political parties. Oddly, Speakers like Jenkins, with established reputations for unusual impartiality, find these circumstances more testing than more partial servants of the government of the day. Government and Opposition pursued increasingly different models of a presiding officer, with the government wanting greater decisiveness and the Opposition wanting greater responsiveness. A fundamental disagreement between government and Opposition emerged over Opposition attempts to test their powers as sponsors of an expenditure bill, which caused Jenkins to think seriously about returning to the government backbench.

Jenkins, who was again elected after the 2010 election, with Slipper nominated as deputy Speaker by the government and elected, resigned on 24 November 2011 to make way for the Gillard government's nomination of Slipper as Speaker. Jenkins was publicly supported by the Opposition at his 2010 election to the 
Speakership, accepting the new paradigm of a reformed parliament announced by Gillard, who argued that the House and not the Speaker comprised the institutional culture required for the Agreement suite of reforms. The three leading speakers at the 2010 election of Jenkins were the Prime Minister as nominator, Leader of the Opposition as seconder, and Oakeshott as a prominent supporter of the new paradigm. Jenkins declared that as part of the new paradigm he would no longer attend ALP caucus meetings.

Slipper was nominated by the government as something of a 'tough cop' model of presiding officer, with the support of the Leader of the Opposition to 'my friend' in his new office. What is important here is that Slipper's election prompted the deputy Speaker into important statements about the new paradigm. In his first statement, Slipper declared that, unlike some of the non-government members of the House, he had not provided any authority to the government of his support for supply or for confidence, and that he had maintained his deliberative vote.

Three significant events took place in 2011, culminating in the resignation of Jenkins. First, on 31 May 2011, in a heated question time, the Speaker gave many warnings to the House about disorderly conduct. At one point, the Speaker formally named one member as deserving a 24-hour suspension, which was moved by Albanese, the Leader of the House. The motion to support the Speaker was lost by one vote: 72 to 71 . The Speaker announced that he would 'consider my position' at this first defeat of a motion to implement his ruling. The Leader of the Opposition quickly moved a motion of support for the Speaker, which was seconded by the Prime Minister, who noted somewhat sharply that the House should always support the Speaker. Oakeshott spoke briefly to explain his opposition to the initial motion on the basis of his general support for free expression of all members. The second motion was not opposed.

On 2 June 2011, Jenkins ruled against a bill introduced by Bishop. The general issue was whether a non-government expenditure bill could override the socalled 'financial initiative' conventions traditionally accepted by the House. The core convention was that the constitution required that all expenditure bills be accompanied by support from the Governor-General consistent with explicit constitutional provisions. Jenkins articulated the House's traditional conventions when ruling against the bill. The Opposition challenged the Speaker with a formal dissent motion, arguing that the House and not the Speaker is the formal authority on such matters (HR 2012: 189-92). The parliamentary debate was again heated, with references to writing by the Clerk over how best to manage this vexed issue. Albanese argued in defence of the Speaker's interpretation of the procedure, and Attorney-General McClelland defended the larger constitutional interpretation of the House's opposition to non-government expenditure bills. The Greens member and the two rural independents from 
New South Wales all called for a new process for expenditure procedures under minority governments. By the end of the debate, the Opposition motion of dissent was lost 72 to 68 votes.

On 24 November 2011, Jenkins announced his resignation: 'placidly with my humour intact'. The positive account of his departure reported that he wanted to return to the ALP to promote good policy measures. The more strategic account mentioned the voting gain won by the government in stealing an Opposition member for the Speakership. The political rhetoric about Jenkins' departure was that he had been pushed out of office to secure the strategic advantage of greater voting strength. In this case, his departure reflects two interesting models of a Speaker. The first is colourless impartiality, which Jenkins discovered prevented an elected member from getting on with the business of promoting good policy. The second is the deeper impartiality found when an Opposition member, like Slipper, resigns from his party and accepts the nonpartisan office of presiding officer. The defect of Slipper's version of this second model is that such impartiality comes at a high price: Opposition interests will do what they can to smear the new Speaker's reputation; and the wider public will not take kindly to misconduct, even when it has no obvious political or, at least, partisan bearing.

The Leader of the Opposition declared that 'something very unusual' was happening and made clear his strong support for the former Speaker. The Prime Minister noted that the deputy Speaker was now acting Speaker, soon to be elected Speaker, with seriously damaging consequences for the Opposition's voting strength. The switch from Jenkins to Slipper effectively gave the government an increase of two ordinary votes. This change was thought necessary as the government numbers might fall at any time through resignation or, just as likely, criminal findings against a member who was at that time facing charges for earlier misconduct as a union official.

\section{Speaker Slipper}

Later on 24 November 2011, Slipper was nominated by the government as an independent member who had resigned from the Opposition party (HR 2012: 166) and was elected Speaker, with Burke from the ALP elected deputy Speaker. He took leave in May 2012 and was replaced by newly elected Burke in October 2012 (Elder 2013: 7-9).

Despite accusations from the Opposition about his inappropriate sexual misconduct and accusations from others about his pre-Speaker breaches of terms and conditions as an elected member, slipper did not fall because of any proven illegality. Nor was he caught in a procedural battle similar to Jenkins. He 
fell because his controversial personal qualities emerged as unsuitable for high public office and it was his personal conduct away from the chamber that eroded his credibility in his official conduct in the chamber.

Slipper's nomination as Speaker provoked outrage from the Opposition, which tried valiantly to nominate any government member for the post. Burke was the first of many government members to decline an offer from Pyne. At one point, the independent Tony Windsor nominated the nominator, Pyne, simply in order to shut him up! The Prime Minister praised Jenkins as 'a great Speaker' before welcoming Slipper's 'fierce sense of balance and appropriateness'. Abbott conceded Slipper's 'technical skills' but wondered hard and long about Jenkins's resignation. As ever, Oakeshott got it right by welcoming the first independent Speaker in the new paradigm; and Slipper later described himself as 'an independent Speaker in the Westminster tradition' (House Hansard 24 November 2011: 13797).

In February 2012 Slipper made two sets of major announcements about his role. On 7 February, he clarified his role in applying the casting vote required of Speakers to break a tied House vote; and he clarified his implementation of an increased number of Opposition supplementary questions during question time. On 8 February, Slipper announced his application of a Speaker's Procession, adapted from the Canadian House of Commons, and further explained his plans for increased number of non-aligned supplementary questions in question time (House of Representatives Practice 172). But, by May 2012, Slipper's hold on the Speakership was weakening. Documents produced in the Federal Court by the prosecution made public Slipper's correspondence in which the language used about male and female sexuality had offensive implications. The later judgement by the Court punished the former political staffer James Ashby team for abusing the court process to ventilate politically explosive documents that did much to discredit Slipper (Farr 2013).

On 9 October, question time was interrupted by an Opposition motion of censure against Slipper, calling on the House to use its constitutional powers under s35 to remove Slipper from the Speakership. The motion was lost by one vote: 70 to 69. Abbott led the attack on Slipper, mentioning his 'misogyny'. This speech provoked the Prime Minister's now famous 'misogyny' speech, in which the accusation was switched from Slipper to the Opposition leader. Other government speeches addressed the imminent Federal Court case against Slipper, calling on the House to avoid premature or rash judgement before the Federal Court had completed its hearing.

Later that day, Slipper resigned, prompting the Opposition leader to declare that Slipper did indeed have good judgement. Slipper's resignation statement made a brave case in defence of his time as Speaker, noting three potential benefits: his 
stately march to open each new sitting day, his use of supplementary questions, and his often admired strict discipline on disorderly conduct. Still later on that day, Burke was elected the third Speaker in the tenure of the Gillard minority government. Burke's election came soon after the funeral for the first female Speaker Joan Child. Strong support for Burke came from the Opposition and non-government members. The Opposition eventually won its own election contest when Coalition member Mr Bruce Scott was elected as deputy Speaker.

\section{Speaker Burke}

Burke's term saw the role of Speaker return from controversy to more conventional modes (Elder 2013: 9-10). The experience of the previous year had upset the standard pathway, however, and released the Speakership from the high degree of respect afforded former Speakers. Burke's time was marked by disruption, as members experimented with new ways (e.g. Twitter) of bringing pressure on opponents; and as visitors brought unwelcome protest into Parliament House. The period was complicated by the fall of Gillard, along with many of her cabinet colleagues, and the return of Rudd as prime minister, leading to the ALP government's loss of office at the 7 September 2013 national election, and the election of a majority Coalition government. Burke's experience of disruption even reached into the election period when she made clear her opposition to Prime Minister Rudd's new direction in asylum seeker protection (Benson 2013).

Burke presided at the time of the judgement by the Federal Court in the case of Ashby v. Commonwealth of Australia (No 4) [2012] FCA 1411 (12 December) (Craven 2012; Marr 2013). The careful 55-page judgement by Justice Rares dismissed Ashby's complaints against Slipper as a political exercise amounting to 'an abuse of the process of the Court', threatening its reputation. Of most importance here is Rares's relative silence about the merits or otherwise of Slipper as an employer, and the emphasis on the political use and abuse of court processes in attempting to secure benefits to the Opposition in the House of Representatives. The judgement is an account of a classic political witchhunt managed by Ashby to discredit Slipper and, so, to damage the Gillard government as his last protector. The case was 'manifestly unfair to Mr Slipper'. The judgement identifies the 'predominant purpose' of the official complaint against Slipper as political rather than legal, resulting in 'irrelevant and scandalous' action in the federal court to discredit Slipper. The management of Ashby's case receives critical examination as a political exercise misusing the legal process for partisan purposes. The court noted that the Commonwealth's case against Slipper's alleged 'Cabcharge' misconduct was a separate issue awaiting determination. 
Burke also made a contribution to the debate between Jenkins and the Opposition. She released a set of 'Update Notes' from the Clerk's office to help members consider the full range of issues relating to 'the financial initiative' (Burke 2013a). This set of papers stand out as the approved procedure for House management of expenditure bills, including those initiated or amended by non-government members. These 'notes' say little about the Speaker, but they say much about the House's established conventions on expenditure bills, which Speakers might well be considered to promote. The issues go to the heart of power relations in a minority government by supporting the Clerk's norm that 'only the government may initiate or move to increase appropriations or taxes' (Clerk's Office 2013: 1). The 'rules' might be clear but the 'application' will require careful judgement by all members of the House and especially the Speaker.

\section{Conclusion}

A number of conclusions arise from this chapter, which has been about the listening powers of the Speaker in the role of presiding officer; Speakers are careful listeners. The most obvious rhetoric of Speakers reflects procedural defects not permitted under the House's standing orders. The 'speaking' roles are largely about procedural orders, especially degrees of punishment given to disorderly members of the House, generally during question time. Few students of political rhetoric would begin to study parliamentary rhetoric through close study of Speakers - because Speakers are not good examples of speakers or orators in the ways expected of party leaders.

The name of the office reflects British tradition regarding the reporting or speaking role of the chief representative of the legislative branch: the one authorised to speak officially about the lower house to other branches of government. This title preceded the later rise of chief ministers, who have assumed vastly greater speaking power, although primarily in relation to the political executive rather than the legislature itself. With the rise of other types of representatives of the legislature, the roles of Speakers have adapted to other forms of institutional management: speaking less but managing more. The best example arising from the three Speakers examined in this chapter is the exemplary British model identified by Rudd when welcoming the first election of Jenkins as Speaker. The newly elected Prime Minister argued in favour of a late-nineteenth century British Speaker who spoke from the chair as little as possible, but with great power and influence.

The House Speaker holds a constitutional and not simply a parliamentary office. The constitution notes that the Speaker does not have a deliberative vote, which explains something important about the role of this office. The absence of a 
deliberative vote is important in the procedure of a deliberative assembly: it suggests that the deliberative assembly does not look to the Speaker to use its casting vote to make a deliberative judgement about the merits of issues caught up in tied votes. A deliberative judgement would be a judgement about the weight and merits of the issue in question. This suggests that the Speaker has non-deliberative themes in mind when making casting votes. One non-deliberative judgement would be a judgement on process, such as the integrity or impartiality of the deliberative process. The casting vote is the only parliamentary vote exercised by the Speaker and this implies that the House has to give close thought to the principles appropriate to casting votes, which might well concern the sort of deliberative processes requiring the attention of Speakers and their procedural advisers. This implication arises from the heartfelt anxiety of debates over the Speakership in the House between 2010-13.

A third conclusion, rising from the dust of the debates over the same period, is that the House elects the Speaker and can dismiss the Speaker. In this period, the House elected three Speakers and caused the standing aside and later the resignation of one Speaker. Again, this relationship derives from the constitution. The implication is that Speakers are servants of the House carrying out duties that are recognised by the House, but which it is not capable of performing: such as the presiding functions seen most obviously during question time. The conclusion is that the election is a delegation but not a source of power, because it can be revoked at any time. The constitution does not set down criteria for election or dismissal. This does not imply that there are no reasons required for either election or dismissal; it simply implies that the House can determine these as it sees fit, taking account of its own accountability to the voters in each electorate. The larger conclusion here is that elected Speakers are protectors of the House's deliberative processes, which is not quite the same as providers of deliberative answers for the House.

A fourth conclusion also derives from the constitution. Section 50 provides for 'rules and orders', but it does not mention the presiding officers as either ruler-makers or order-makers. Each House may make rules and orders relating to its 'powers, privileges and immunities'; and about the 'order and conduct of its proceedings'. The implication is that the House may authorise rules and orders, and may require Speakers to manage many of the rules and orders, but the constitution does not establish the Speaker as the source of rules or orders. Speakers might well advise the House on preferred rules and orders, and might well manage the House's own preferred rules and orders, but Speakers are not delegated with rule-making powers because the House itself has that important constitutional function. Speakers are functionaries, reflecting the House as its representative, presiding over the many deliberative processes required of this deliberative assembly. 
Studies in Australian Political Rhetoric

\section{References}

Andrew, N. 2002. The Australian federal Speakership. Unpublished speech delivered at University of Adelaide, 17-18 August.

ABP 2010. Agreement for a better Parliament: Parliamentary reform. Canberra, 7 September.

Benson, S. 2013. Speaker buckets Rudd on refugees. Telegraph 6 August: 7.

Bolton, G. 1968. The choice of the Speaker in Australian Parliaments. In C.A. Hughes ed. Readings in Australian government. University of Queensland Press, 155-62.

Brandis. G. 2010a. Re: S.40 of the Commonwealth Constitution. 20 September.

- 2010b. Critique of the opinion of the Commonwealth Solicitor-General. 23 September.

2010c. Australian Senate, 26 October: 827-29.

Bryce, J. 1889. The American Commonwealth. London: Macmillan.

Burke, A. 2013a. Law making powers of the Houses. House Hansard, 14 May, 34. 2013b. 'The organisation of private Members' business'. Regional Presiding Officers Conference. Canberra, July.

Clerk's Office 2013. The law making powers of the Houses: Three aspects of the financial initiative. Canberra: House of Representatives 13 May.

Craven, P. 2012. The end of the (Slipper) affair. The Drum Opinion 18 December.

Elder, D. 2013. The role of the Speaker in minority government. Unpublished paper. Canberra.

Farr, M. 2013. Revealed: What Peter Slipper's sexist text messages actually said. Australian 9 October.

Gageler, S. 2010. In the matter of the Office of Speaker of the House of Representatives. SG no. 37 of 2010. Canberra: Solicitor-General of Australia.

Healy, M. 1998. The independence of the Speaker. Canberra: Parliamentary Library.

HR 2008. The Speaker of the House of Representatives. 2nd edition. Canberra.

2012. The Speaker, Deputy Speakers and officers. Chpt 6 in House of Representatives practice. 6th edition. Canberra. 
2013. Infosheet 3 - The Speaker. Canberra.

Inglis, K. 1996. Parliamentary speech. Australian Journal of Law and Society 12: 147-62.

Marr, D. 2013. Ashbygate. Guardian Australia 12 July.

Milne, G. 2010. 'Exclusive: Oakeshott makes a bid for Speaker', The Drum Opinion, 15 September.

Murray, J. 2002. The role of the Speaker and political reality. Conference of Association of Clerks at the Table. July, Brisbane.

Quick, J. and Garran, R. 1976 (1901). The annotated constitution of the Australian Commonwealth. Sydney: Legal Books.

Remuneration Tribunal 2012, 2013. Report no. 1 of 2012; Determination no. 13 of 2013.

Snedden, B. 1980. Ministers in parliament - a speaker's eye view. Politics 15(2): 68-85.

Wright, B. 2013. Hung parliaments - are they good for parliament? ASPG Victorian Chapter Seminar. Canberra. 
This text taken from Studies in Australian Political Rhetoric, Edited by John Uhr and Ryan Walter, published 2014 by ANU Press, The Australian National University, Canberra, Australia. 